\title{
0 DEBATE ENTRE A CULTURA POPULAR E A CULTURA ERUDITA NO CARNAVAL CARIOCA
}

Zilmar Luiz dos Reis Agostinho (Uerj)

No projeto pensado pelas elites republicanas, as classes populares estavam alijadas de qualquer participação política mais efetiva, sendo suas manifestações culturais também vistas como objetos que representavam o atraso do Brasil em relação aos países "civilizados". Uma dessas manifestações "indesejáveis" era o samba que, assim como as escolas de samba, tem origem nos espaços segregados do Rio de Janeiro. As escolas de samba, que surgem no final da década de 1920, refletem uma nova forma de as classes populares brincarem o carnaval. Posteriormente, com seu reconhecimento como manifestação de cultura popular, as escolas de samba sofreram, no início de sua existência, tentativas de controle ao ser impedidas, por exemplo, de manifestar temas políticos ou reivindicatórios. Com o surgimento do carnavalesco, passa a haver nas agremiações um novo padrão estético, que se torna alvo de críticas por supostamente atender ao gosto estético das elites, fazendo com que as escolas de samba percam seu caráter popular.

\section{CULTURA POPULAR; CULTURA ERUDITA; ESCOLA DE SAMBA.}

AGOSTINHO, Zilmar Luiz dos Reis. O debate entre a cultura popular e a cultura erudita no carnaval carioca. Textos escolhidos de cultura e arte populares, Rio de Janeiro, v.11, n.2, p. 67-89, nov. 2014. 


\section{THE DEBATE BETWEEN}

\section{POPULAR AND HIGH CULTURE}

\section{IN THE CARNIVAL OF RIO DE JANEIRO}

Zilmar Luiz dos Reis Agostinho (Uerj)

In the project thought by the republican elites, popular groups were deprived from a more effective political participation, while their cultural manifestations were seen as representative of the delay of Brazil in relation to "civilized" countries. One of these "undesirable" manifestations was the samba which, like the samba schools, has its origin in segregated spaces of Rio de Janeiro. The samba schools, which emerged in the late 1920s, reflect a new way for popular groups to enjoy Carnival. Subsequently, from its recognition as a manifestation of popular culture, at the beginning of its existence the samba schools suffered attempts of control as they were barred from expressing political or demanding themes, for example. With the emergence of the "carnavalesco", a new aesthetic standard is settled in the samba schools, which then become a target for allegedly meeting the elite's aesthetic style, making the samba schools lose their popular character.

HIGH CULTURE; SAMBA SCHOOL; POPULAR CULTURE.

AGOSTINHO, Zilmar Luiz dos Reis. O debate entre a cultura popular e a cultura erudita no carnaval carioca. Textos escolhidos de cultura e arte populares, Rio de Janeiro, v.11, n.2, p. 67-89, nov. 2014. 
O presente artigo tem por objetivo estabelecer um diálogo entre a cultura popular e a cultura erudita no carnaval do Rio de Janeiro. As elites políticas buscaram de alguma maneira controlar as manifestações de cultura popular, vistas como indesejáveis a seus ideais civilizatórios, mais afeitos ao padrão europeu.

Essa tentativa de controle também se deu no carnaval, quando as elites tinham por objetivo eliminar o entrudo (também praticado por elas), resquício de um passado rudimentar e colonial, de acordo com sua perspectiva. A substituição ideal seria feita pelos bailes de máscaras nos salões e pelo desfile das grandes sociedades que efetivamente ocupariam as ruas do Rio de Janeiro, sobretudo na área central, dando um ar parisiense ao carnaval carioca, organizando-o e hierarquizando-o, em uma espécie de "reinversão" da festa.

$O$ ar parisiense também foi pensado para a transformação da área central do Rio de Janeiro no início do século XX, causando a expulsão de um grande número de habitantes, que passaram a viver no entorno dessa área central. Justamente em uma dessas novas áreas de ocupação surgiu o que conhecemos como samba moderno, mais uma manifestação cultural popular amplamente perseguida pelas elites.

O samba passou por transformação realizada por um grupo morador do bairro do Estácio de Sá que gostaria de brincar o carnaval embalado por suas composições. Estava fundada a primeira escola de samba.

Frutos da criação popular, pouco tempo depois alcançam a oficialização que garantiria também subvenção para seu desfile. Essa oficialização é considerada uma forma de controle por parte do poder público, haja vista o estabelecimento de um regulamento para os desfiles.

Mesmo sendo as escolas de samba controladas pelo poder público (um dos braços da elite), a criação de seu desfile ainda era totalmente pensada pelos membros que dela participavam diretamente.

Haveria, contudo, mudança significativa com a entrada de um profissional especializado em artes plásticas que posteriormente ficaria conhecido como "carnavalesco". Esse profissional muda os aspectos estéticos das escolas de samba, passando a conceber totalmente o enredo. As críticas a seu trabalho chegam na mesma proporção que as mudanças impostas, pois são acusados de ser representantes da cultura erudita interferindo na cultura popular, de estar mais preocupados em valorizar seu trabalho em detrimento do "verdadeiro" sentido da festa. 


\section{O COMBATE À CULTURA POPULAR}

Com o advento da República em finais do século XIX, as elites políticas buscavam inserir o Brasil na chamada modernidade, porém a participação da maior parte da população não estava contemplada em seu plano, que tinha como um de seus pilares suplantar o atraso representado pela monarquia e pela escravidão, sendo, portanto, as classes populares consideradas indesejáveis aos ideais civilizatórios, exclusivamente direcionados às elites.

Além da eliminação da participação popular nos rumos da política republicana, outro objetivo das elites consistia em suprimir qualquer manifestação de cultura popular que, juntamente com seus valores, era estigmatizada como manifestação de atraso, que maculava a imagem da civilidade das classes dominantes (SOIHET, 1998). Letícia Reis (2003, p. 242) complementa essa ideia afirmando:

Na verdade, o esforço conjunto das elites e do governo oligárquico da Primeira República ia no sentido da contenção das assim denominadas "classes perigosas", especialmente no tocante à sua herança africana. Contudo, (...) a presença negra foi, pouco a pouco, se fazendo sentir na cidade.

Podemos perceber, portanto, que mesmo com o claro objetivo de conter as chamadas classes perigosas, as elites não foram capazes de eliminar as heranças culturais das classes populares, pois "o oficialismo da vida cultural sempre voltada para o cenário europeu coexistia com expressivas tradições nacionais marcadas, sobretudo, pela influência da cultura negra" (VELloso, 2007, p. 363).

Tais manifestações eram, em grande parte, postas em marcha durante 0 carnaval, quando as classes populares podiam exprimir-se livremente, concretizando aquilo que Mikhail Bakhtin (1999) chama de segunda vida. Era durante o carnaval que as distâncias entre o povo e a elite eram eliminadas, ainda que de maneira efêmera, pois "ao contrário da festa oficial, o carnaval era o triunfo de uma espécie de liberação temporária da verdade dominante e do regime vigente, de abolição provisória de todas as relações hierárquicas, privilégios, regras e tabus" (p. 8).

Uma das formas de brincar o carnaval mais combatidas no início da República, o entrudo, não tinha origem africana, mas sim europeia. Consistia no lançamento de objetos preenchidos com os mais variados líquidos, tivessem eles o odor que tivessem. Essa brincadeira não era exclusividade do Rio de Janeiro; também ocorria em Salvador e, de acordo com Peter Fry, Sérgio Carrara e Ana Luíza Martins-Costa (1988), em finais do século XIX, começava a incomodar.

Importante lembrar que o entrudo era praticado durante o carnaval muito antes da abolição da escravidão e da proclamação da República, sendo identifica- 
do no Brasil já no século XVI (FERREIRA, 2005). De acordo com Eneida de Moraes (1987), o carnaval do entrudo dava a possibilidade aos escravos, por exemplo, de criticar e escarnecer de seus senhores. Essa oportunidade não era dada apenas aos escravos, mas também às pessoas livres, que assim encontravam uma forma de se "vingar" de seus desafetos.

por volta das dez e meia da noite, em pleno centro da cidade, Ângela caminhava feliz e brejeira atrás de sua máscara pela rua Luiz de Camões quando, ao longe, avistou um desafeto que, por azar, era também um policial do corpo dos urbanos. Deve ter se animado com a oportunidade: esta ainda era, para boa parte dos cariocas, a maior graça do Carnaval (CUNHA, 2001, p. 21-22).

O interessante da passagem acima é a zombaria destinada àqueles com os quais não se possui afinidade - no caso da personagem, um policial, pouco propenso a brincadeiras. Essa zombaria, esse escárnio, é o que Bakhtin (1999) chama de riso festivo, pois o que Ângela faz, ao se dirigir mascarada até seu desafeto para dele caçoar, não é simplesmente rir de um fato isolado, mas sim um riso "dirigido contra toda superioridade", representada no trecho citado pela autoridade policial.

É preciso assinalar que, embora as proibições do entrudo se sucedessem, ele continuou a ser praticado; os escravos que fossem pegos durante a brincadeira seriam, entretanto, passíveis de punição, como aponta um edital de 1857, em parte transcrito por Moraes (1987, p. 37). O edital proibia a prática do entrudo na cidade do Rio de Janeiro e, em caso de desobediência, haveria o pagamento de multa. Caso o desobediente não tivesse como pagá-la, ficaria preso por oito dias, se seu senhor não mandasse dar-Ihe cem chibatadas. Ora, pelo edital transcrito, os únicos que poderiam ser punidos de fato eram os escravos, embora todas as classes sociais participassem da brincadeira.

Mesmo podendo contar com a participação de escravos, é necessário, porém, alertar que "longe de representar um momento de nivelamento da sociedade, (...) ou uma inversão, mesmo que momentânea, dos valores estabelecidos, o entrudo reflete e dramatiza a organização social do espaço urbano onde ele se inscreve" (FERREIRA, 2005, p. 29-30).

Logo, embora o carnaval do entrudo fosse uma festa de inversão, da liberdade, da qual Bakthin nos fala (sem querermos incorrer em anacronismos), havia também uma hierarquização da festa, ainda que essa hierarquia não fosse estabelecida diretamente pelo Estado (como ocorrerá mais adiante); era imposta pelos próprios participantes. Percebemos, então, que Felipe Ferreira não concorda com Moraes, quando a autora afirma que o entrudo era uma forma que os escra- 
vos encontravam para caçoar de seus senhores. Tal fato poderia até acontecer no uso de fantasias, mas nunca no lançamento de projéteis ou água sobre os seus senhores. Essa hierarquia demonstra que, para o autor, não havia somente um entrudo, mas vários entrudos.

dentro das casas brincavam as famílias - respeitando-se a diferenciação de nível econômico e social e utilizando-se de projéteis mais sofisticados, como as laranjas e limões-de-cheiro -, enquanto nas ruas, os negros, os pobres, os ambulantes, as prostitutas e os moleques molhavam-se e sujavam-se com polvilho, pó de barro, águas de chafarizes e de sarjetas e um ou outro limão-de-cheiro roubado das casas senhoriais (FERREIRA, 2005, p. 30).

Peter Fry, Sérgio Carrara e Ana Luíza Martins-Costa (1988, p. 243), ao estudar a prática do entrudo no carnaval de Salvador, chegam à mesma conclusão sobre a hierarquização que Ferreira, pois

As hierarquias que regem as relações entre brancos e negros no seio da sociedade escravista e patriarcal daquela época continuam operantes durante as festividades do entrudo. A "guerra" do entrudo não modifica o contato entre segmentos sociais que estão segregados, mas antes reforça sua separação, pois a posição inferior dos negros em relação aos brancos permanece inalterada. Os negros brincam o entrudo entre si, sem que se altere a distância social que os separa dos brancos. Já os "rapazes brancos", devido à sua posição social, podem se divertir em jogar água ou farinha nos pretos "sem nenhuma cerimônia"..

É justamente esse entrudo dos negros (e dos pobres) que passou a ser combatido veementemente pelas elites, que temiam o alvoroço causado por esse carnaval, bem como a grande massa que andava mascarada pelas ruas do Rio de Janeiro. Era por meio dessas máscaras, juntamente com as fantasias, que as identidades poderiam ser escondidas, pois

dias de exceção, o Carnaval fazia com que o ocultamento da identidade - lido como quebra da hierarquia e da diferenciação - aparecesse como um elemento assustador, em particular nas condições do Rio de Janeiro, cuja imensa população negra era cada vez mais indiferenciada em sua condição civil de forros ou cativos (CUNHA, 2001, p. 40).

A prática do entrudo, ainda que fosse mantida na esfera privada, precisava ser eliminada da esfera pública, das ruas, como afirmou o prefeito do Rio de Janeiro, Pereira Passos, em 1904, em entrevista ao jornal Gazeta de Notícias, transcrita por Moraes (1987, p. 41). O então prefeito afirma ser inaceitável que 
se pratique o entrudo na rua, que para ele era uma "distração perigosa", mas que não podia proibir a prática na esfera privada, pois "quem quiser molhe e seja molhado".

Além do cuidado com uma questão de saúde pública, a principal preocupação de Pereira Passos, como um político da Primeira República, era o "perigo" que o entrudo representava para os ideais civilizatórios das elites. Para elas fazia-se necessário remodelar também o carnaval, eliminar o incivilizado entrudo de origem lusitana e o caos que o acompanhava, e substituí-lo por um carnaval à "francesa", "impondo à festa a ideia de ordem, de regulamentação e de purificação, tão cara ao século XIX" (FERREIRA, 2005, p. 32).

Essa perseguição ao entrudo e a remodelação do carnaval, de acordo com Fry, Carrara e Martins-Costa (1988, p. 244), estavam ligadas a uma segunda vertente que era a modificação do significado do espaço público. A rua não mais poderia ser uma extensão da casa, mas deveria ser adequada para o usufruto das elites. Para os autores, a rua

deve se preparar em termos estéticos, higiênicos e disciplinares, para a emergência de uma elite urbana republicana e abolicionista que necessita de um cenário condizente com as novas prerrogativas políticas que se arrogam. (...) E nela não parece mais haver lugar para ruas encharcadas e sujas, para senhores e senhoras moIhados e descompostos, e para negros ruidosos e alegres.

A passagem acima nos faz relembrar que o entrudo a ser combatido com veemência era aquele praticado pela população mais pobre e não aquele jogado ou brincado pelas elites em suas residências. Coexistindo com o entrudo, havia o carnaval proporcionado pelas grandes sociedades, mais afeito ao gosto das elites. As grandes sociedades nada mais eram do que a transposição para a rua daquilo que ocorria nos bailes de máscaras realizados nos clubes, em um "processo de apropriação simbólica característica das festas processionais" (FERREIRA, 2005, p. 62).

Essa ocupação das ruas pelas elites durante a festa era uma importação do carnaval que ocorria em Paris, onde elegantes senhores desfilavam pelos amplos boulevards com suas máscaras e fantasias. A primeira grande sociedade, cujo nome era Congresso das Summidades Carnavalescas, ainda que não contasse com os boulevards, alcançou grande sucesso já em seu primeiro desfile, em 1855, estabelecendo novo marco no carnaval carioca, talvez o início da organização e da apropriação das ruas pelas elites durante os festejos. $\mathrm{O}$ desfile da primeira grande sociedade parece ter encorajado as elites a sair às ruas para se divertir nos dias dedicados à festa, conforme as palavras de Ferreira (2005, p. 66): "a elite 
carioca já começa a se sentir segura, e apoiada, em sua marcha para ocupar, com seus divertimentos carnavalescos, o espaço urbano da cidade."

Podemos perceber que o desfile das grandes sociedades nada mais era do que uma tentativa por parte das elites de hierarquizar as ruas também durante o carnaval, pois ainda que esse movimento coexistisse com o "entrudo do povo", o entrudo sujo e brutal, este último deveria ser de uma vez por todas eliminado do carnaval carioca.

Os desfiles das grandes sociedades reforçavam as posições hierárquicas da sociedade carioca, dando ao carnaval uma característica de festa oficial, invertendo a função da festa descrita por Bakhtin (1999), para quem a festa oficial - a do Estado e da Igreja - tinha por objetivo separar propositadamente as classes, situação em que "cada personagem apresentava-se com as insígnias dos seus títulos, graus e funções e ocupava o lugar reservado para o seu nível”.

Já no caso do carnaval, ainda segundo Bakhtin (1999), a festa deveria servir como um mecanismo de superação das desigualdades, mesmo que momentânea, entre "indivíduos normalmente separados na vida cotidiana pelas barreiras intransponíveis da sua condição, sua fortuna, seu emprego, idade e situação familiar".

Exageros à parte, pode-se dizer que o carnaval representado pelas grandes sociedades desfazia a inversão da festa, ao impor a separação entre quem poderia participar e quem estava limitado apenas a assistir o seu passar pelas ruas do Rio de Janeiro. Não é preciso dizer que, também por razões econômicas, a maioria do povo estava impedida de participar dos desfiles elitizados das grandes sociedades.

Além de brincar o carnaval à moda francesa, outro projeto pensado pelas elites era a transformação da então capital da República em uma espécie de "nova Paris". Esse projeto começou a ser posto em marcha já nos primeiros anos do século XX, através das reformas urbanas empreendidas pelo prefeito Pereira Passos, que buscaram eliminar os cortiços e as habitações humildes, expulsando a população "indesejável” da área central da cidade, pois o novo Centro da cidade, com sua arquitetura e equipamentos urbanos, deveria ser desfrutado apenas pelas elites (REIS, 2003). Ordenava-se assim, quase que ao mesmo tempo, o carnaval e a cidade. Vale relembrar que esse ordenamento era feito não ao acaso, mas segundo um modelo real conhecido e consagrado pelas elites, tanto em seu urbanismo quanto em seu carnaval, no caso Paris.

A população expulsa da área central da cidade, impedida também de brincar o carnaval nesse lugar, teve que criar e recriar novas maneiras de se expressar durante a festa, embora as elites continuassem a perseguir "as heranças afri- 
canas" da população. A separação do carnaval parecia naquele momento consolidada, pois as elites comandavam a festa através dos bailes de máscaras e dos desfiles das grandes sociedades, enquanto o carnaval das classes populares se retraiu do Centro para os bairros [subúrbios] e ganhou força nos morros e favelas (SEBE, 1986). Essa separação deu origem àquilo que Sérgio Cabral (1996, p. 24). chama de pequeno e grande carnaval:

O pequeno carnaval era constituído pelos agrupamentos formados pelas camadas mais baixas da população - os cordões, os ranchos e, mais tarde, as escolas de samba. O grande carnaval era o dos Fenianos, dos Tenentes do Diabo, dos Democráticos, etc., isto é, das grandes sociedades.

Foi justamente nos lugares do "pequeno carnaval", para onde se dirigira uma parte daquelas classes populares expulsas pelas reformas urbanas, que surgiu o samba moderno, tendo sido apontada a Praça Onze de Julho, mais conhecida atualmente como Praça XI, como o berço desse ritmo musical. Também nesses lugares, aconteciam rituais de candomblé, sobretudo nas casas das chamadas "tias", entre elas a da famosa "tia" Ciata, ${ }^{1}$ apontada como local de nascimento do primeiro samba gravado de sucesso, "Pelo telefone", de autoria dos compositores Donga $^{2}$ e Mauro de Almeida. ${ }^{3}$ De acordo com Cabral, essa composição estabeleceu um novo marco no carnaval carioca, pois foi a partir dela que o samba começou a assumir a primazia nos festejos do mês de fevereiro.

Um dos fatores responsáveis por esse novo status atingido pelo samba foi a interação entre a cultura popular e a cultura erudita, proporcionada pela atuação de mediadores culturais (VIANNA, 2007). Hermano Vianna (2007) aponta um encontro acontecido em 1926 - narrado por Gilberto Freyre - entre essas duas camadas da sociedade, no qual Freyre, Prudente de Morais Neto, Heitor Villa-Lobos e Luciano Gallet foram a "uma noitada de violão", cujos anfitriões eram Donga, Patrício Teixeira e Pixinguinha. ${ }^{4}$ Esse encontro, na opinião do autor, foi emblemático, já que reunia, "de um lado, representantes da intelectualidade e da arte erudita, todos provenientes de "boas famílias brancas". . Do outro lado, músicos negros ou mestiços, saídos das camadas mais pobres do Rio de Janeiro (p. 20).

$\mathrm{O}$ autor faz um alerta para que não pensemos que tal encontro tenha sido singular, tampouco o primeiro -estava inserido em uma longa tradição de contato entre a elite brasileira e as várias manifestações de musicalidade afro-brasileira. Antes mesmo desse encontro já se percebia uma interação direta entre os sambistas e a elite política brasileira. Uma passagem marcante dessa interação pode ser vista a seguir: 
Foi também a apreensão de um pandeiro na famosa Festa da Penha que deu origem a uma passagem dessa mesma imbricação entre a ordem e a desordem. Nela estiveram envolvidos o afamado sambista João da Baiana, ${ }^{5}$ filho de baianos, e, nada mais nada menos do que o caudilho gaúcho senador Pinheiro Machado, um dos políticos mais influentes da República Velha (REIS, 2003, p. 254).

O sambista João da Baiana afirma em seu depoimento ao Museu da Imagem e do Som do Rio de Janeiro, transcrito por Cabral, que havia sido convidado para participar de uma festa na casa do senador Pinheiro Machado, mas não compareceu porque o seu pandeiro havia sido apreendido pela polícia na Festa da Penha. O senador, então, o chama ao Senado e pergunta o motivo de sua ausência. Obtendo a resposta do sambista, o senador pergunta se João da Baiana havia brigado e onde poderia se fabricar o instrumento e, com a indicação do lugar feita pelo sambista, o senador lhe entrega uma ordem para que fosse fabricado um novo pandeiro com uma dedicatória sua. A dedicatória, então, passou a funcionar como uma espécie de salvo-conduto, pelo menos para João da Baiana.

Nelson Fernandes (2001), contudo, alerta sobre o perigo de pensarmos que episódios como o descrito acima, postos como exemplos de intercâmbio cultural, possam ter acabado ou sequer minimizado as perseguições aos sambistas ou a qualquer manifestação de cunho popular. Vejamos sua explicação:

O que queremos realçar é que a presença popular nos salões presidenciais e de políticos como Pinheiro Machado não conduziu a classe dirigente a imaginar que deveria tratar os romeiros e os negros da Festa da Penha como cidadãos. Ao contrário, eles permitiram que sua polícia desordeira e arbitrária se voltasse contra os grupos populares (...) desde que as condições fossem favoráveis, as forças de segurança não perderam a oportunidade de exibir irracionalidade e violência (FERNANDES, 2001, p. 85).

O preconceito ainda muito presente em nossa sociedade pós-abolição levava os mecanismos estatais (sobretudo a polícia) a empreender verdadeira perseguição àquilo que era considerado fora dos padrões de uma sociedade civilizada. As páginas policiais registravam diversas prisões de pais e mãe de santo, além da detenção de qualquer pessoa que portasse algum instrumento musical, digamos, "mais popular", como afirma o compositor Donga em depoimento a Hermínio Belo de Carvalho, em 1963, transcrito, parcialmente, por Cabral. De acordo com Donga, a pessoa que fosse pega portando um violão, por exemplo, era "pior que comunista". 
Ana Maria Rodrigues (1984) completa essa ideia afirmando que o fato de as festas populares ocorrerem, muitas vezes, no interior das residências não as livrava das constantes repressões policiais.

Diferentemente do período de perseguição ao entrudo, quando as elites buscavam não interferir na brincadeira no interior das casas, limitando-se a perseguir o "entrudo de rua", podemos perceber que, com o samba e/ou com as manifestações religiosas de cunho afro-brasileiro, a relação era bastante conflituosa.

A repressão se dava principalmente porque essas manifestações culturais não representavam aquilo que as elites desejavam como um ideal de civilidade; não era dada permissão para que existissem nem sequer nos subúrbios e morros nos quais as classes populares estavam confinadas. O preconceito faz com que não se aceite o outro apenas como culturalmente diferente, mas procura estigmatizá-lo como "aculturado", prolongando a desigualdade. Sobre isso, Rogério Haesbaert (1999, p. 176) observa que "a diferença (...) cultural, portanto, tende a diluir-se na desigualdade, e o extremo dessa transformação é dado pelo racismo - nele, a diferença do outro se transforma na sua estigmatização, no seu 'rebaixamento', na sua depreciação".

As classes populares tentam resistir às constantes pressões por parte das elites que, incapazes de aceitar, de conviver com algo que fugisse aos seus padrões de comportamento, lhes negavam o direito de manifestar sua cultura no espaço privado e, principalmente, no espaço público. Um dos meios encontrados pelas classes populares para manifestar sua cultura acontecia nas chamadas "casas de macumba", que passaram a funcionar legalmente devido à atuação de alguns políticos. Foi justamente por meio desses espaços religiosos que o samba começou a ganhar mais espaço, pois os sambistas aproveitavam-se do final dos cultos de candomblé para cantar e dançar o samba. Como dificilmente as autoridades policiais possuíam capacidade de diferenciar o samba dos cânticos religiosos, os sambistas tinham nesses espaços certa "liberdade" de atuação. Dizemos certa "liberdade" porque, em alguns casos, havia policiais que, disfarçando-se, conseguiam inserir-se nas rodas de samba, devido a sua origem, digamos, mestiça, e assim efetuavam as prisões.

\section{O SURGIMENTO E O “CONTROLE” DAS ESCOLAS DE SAMBA}

Apesar da profunda repressão sofrida, o samba resistiu, foi remodelado, reinventado, pois as composições não eram adequadas para brincar o carnaval. O samba recebe, então, novo tratamento por um grupo de jovens compositores do bairro do Estácio de Sá - para onde se dirigiu uma parte das classes populares após as reformas de Pereira Passos -, que queriam adequar o ritmo aos desfiles 
dos blocos. Foi aí que decidiram criar um bloco carnavalesco que sairia pelas ruas cantando suas composições.

Vemos que o samba moderno nasceu do atendimento consciente de uma necessidade de um tipo de música que permitisse aos blocos e cordões dançarem o samba, sendo, portanto, muito mais uma questão de inovação do que tradição. A nova música foi tão consequente em seus propósitos que resultou numa manifestação carnavalesca que revolucionará seus desfiles processionais (FERNANDES, 2001, p. 47).

Ao inovar a maneira de fazer o samba, os compositores do Estácio de Sá estavam criando também uma nova maneira de desfilar, uma reinvenção para que as classes populares se fizessem notar não somente durante o carnaval, mas também no espaço carioca. O samba seria uma das formas que as classes populares encontraram para se integrar à cidade, como observa Fernandes (2001, p.47):

Parece existir nas origens do samba moderno uma feliz teleologia de uma nova geração de sambistas liderada por jovens pobres, quase todos pretos e moradores do bairro do Estácio, que muito rapidamente, como se numa operação coordenada, serão seguidos e superados por muitos dos seus pares que abundavam nas favelas e nos subúrbios, tão ou mais necessitados de exprimir sua existência na cidade, de ao menos simbolicamente conquistar a cidade.

Podemos perceber que Fernandes usa a palavra simbolicamente porque as elites ainda negavam às classes populares qualquer participação nas decisões sobre os rumos do país. Até nas manifestações culturais populares essas elites buscavam intervir, primeiro permitindo sua existência, depois passando a patrociná-las até chegar a interferir diretamente na própria concepção dos desfiles, como veremos adiante.

Inconscientemente, os sambistas do Estácio estavam criando a primeira escola de samba, na qual

explorava-se o exotismo contido nas canções, nos instrumentos e, principalmente, na dança. Era como se existisse uma necessidade latente de mostrar à população branca dominante, o que os negros pobres faziam no morro. Era a forma de trazer para o asfalto sua realidade social (RODRIGUES, 1984, p. 34).

O surgimento da Deixa Falar (a primeira escola de samba) e das demais que a ela se seguiram foi um dos elementos que possibilitaram a identificação das classes populares com os lugares em que viviam. Sobre esse assunto, Fernandes (2001) afirma que as escolas de samba conseguiram melhorar o ambiente social 
dos morros e favelas, tão estigmatizados como lugares de selvageria e incultura e, além disso, "muitos destes bairros e favelas não se explicam sem suas escolas de samba porque, dentre outras coisas, às vezes funcionariam como centros de resistência contra os processos e as políticas de remoção" (p. 10).

Importante salientar que a Deixa Falar nunca foi na realidade uma escola de samba, mas sim um bloco. Ela recebeu esse nome porque o grupo que fundou o bloco morava - assim como ficavam os bares em que se reuniam - nas proximidades de uma escola que formava professores; como os sambistas consideravam saber tudo sobre samba, também eram professores, e a Deixa Falar, consequentemente, uma escola de samba.

Mesmo tendo existência muito curta, já que durou menos de cinco anos, não se pode negar a importância, tampouco a primazia, da Deixa Falar enquanto escola de samba, cujo título foi absorvido por outros blocos carnavalescos que já existiam ou surgiram no espaço carioca, dando início a uma nova forma de brincar o carnaval.

Longe de querer discutir aqui a questão levantada por Michel Vovelle (1985) sobre os limites entre os campos da ideologia e da mentalidade - principalmente pelo fato de que este último ainda representa um risco por ser "voluntariamente empírico" -, poderíamos chamar aqui de imaginário coletivo a afetividade que as escolas de samba criam, pois cada membro da agremiação se sente responsável e solidário perante ela.

Decifrar os processos que levam os componentes de uma escola de samba a se sentir participantes dela é tarefa bastante complicada; afinal a cultura, segundo Clifford Geertz (1989, p. 9), criticando Stephen Tyler, um dos porta-vozes do cognitivismo, não pode ser estudada por meio de "métodos formais similares aos da matemática e da lógica". Saber o que é uma escola de samba não significa entender de fato o que seja uma escola de samba nem quais são realmente seus significados. Só quem tem afinidade, afetividade com as agremiações é capaz de estabelecer esse verdadeiro significado, pois tudo aquilo que se produz acerca das agremiações nada mais é do que um jogo de "interpretações e, na verdade, de segunda e de terceira mão (...). Trata-se, portanto, de ficções; ficções no sentido de que são 'algo construído', 'algo modelado' (...) não que sejam falsas, não fatuais ou apenas experimentos de pensamento" (GEERTZ, 1989, p. 11).

De acordo com Rodrigues (1984, p. 19-20), "as escolas de samba nasceram como associações voluntárias e de caráter integrativo, tendo o seu surgimento sido motivado pela necessidade social do grupo negro de manter algum tipo de identidade". 
Essa identidade só se torna possível porque "ela recorre a uma dimensão histórica, do imaginário social, de modo que o espaço que serve de referência 'condense' a memória do grupo" (HAESBAERT, 1999, p. 180). Milton Santos (2004, p. 326) complementa essa ideia ao dizer que "a cultura, forma de comunicação do indivíduo e do grupo com o universo, é uma herança, mas também um reaprendizado das relações profundas entre o homem e o seu meio". Podemos inferir a partir das passagens acima, portanto, que as identidades surgidas em torno das escolas de samba só se tornaram possíveis porque elas foram capazes de tornar coletivas as memórias do grupo que as criou.

Sendo frutos dos espaços segregados do Rio de Janeiro, as escolas de samba definiram um limite entre aqueles que participavam diretamente delas e aqueles que não tomavam parte do "mundo do samba". Mesmo dentro desse "mundo", porém, havia uma relação de poder, uma liderança que era exercida não necessariamente pelo presidente da escola, mas também por um indivíduo muito respeitado no morro ou no bairro, como por exemplo, Paulo da Portela. ${ }^{6}$ As lideranças dentro das escolas de samba foram essenciais para sua manutenção, pois personagens como Paulo da Portela se encarregavam de se relacionar com organismos alheios a seu "mundo", expediente que, com o passar do tempo, se tornou cada vez mais recorrente.

Esse relacionamento entre sambistas e não sambistas possibilitou o primeiro concurso entre as escolas de samba que aconteceu, como não poderia ter sido diferente, na Praça XI, lugar apontado, como dissemos, como o do nascimento do samba e que ficava no centro da região ocupada pela comunidade negra do Rio de Janeiro.

Mesmo com o relativo sucesso alcançado, devemos lembrar que as escolas de samba ainda levavam desvantagem no que se referia à atenção dos cronistas que cobriam o carnaval, já que as grandes sociedades ainda despertavam maior interesse dos jornais.

Ainda que suas manifestações culturais começassem a ser percebidas, as classes populares ainda eram obrigadas a festejar nos lugares a elas destinados, longe do entorno da Avenida Rio Branco, lugar reservado aos festejos da elite carioca.

As escolas de samba eram não só obrigadas a concorrer entre si e com outras manifestações de cunho popular, mas também tinham que disputar a atenção com as manifestações carnavalescas das elites, o que nos faz afirmar, em concordância com Fernandes (2001), que a consolidação das escolas de samba ocorreu em um espaço festivo múltiplo e não em um espaço ausente de festas. Havia, desse modo, se não uma disputa pela primazia da festa, ao menos uma tensão. 
Devemos também considerar que as festividades populares não só concorrem entre si como também disputam a cena pública com os grupos de elite e suas festas oficiais. Estudos e crônicas do Carnaval carioca registram que até os anos 30 ele era dominado por manifestações associadas aos grupos superiores e médios como as grandes sociedades, ranchos e corsos. Assim, a afirmação das escolas de samba não se deu num espaço festivo vazio, onde no máximo havia rituais decadentes, sobrevivências do tempo colonial, da sociedade escravista ou do mundo rural (FERNANDES, 2001, p. 6).

O jogo de poder aqui é bastante desigual, haja vista que, além de terem que resistir ao preconceito das elites, as classes populares eram obrigadas a conviver e disputar a atenção com o carnaval dessas elites.

Já se tornara impossível, porém, não reconhecer o sucesso das escolas de samba como parte do cenário festivo carioca, importância essa que foi atestada pela oficialização dos desfiles das escolas de samba, registrada pelo decreto municipal assinado na ocasião pelo prefeito Pedro Ernesto, datado de 02 de fevereiro de 1935. Esse decreto garantia não só a oficialização das escolas de samba como participantes do carnaval carioca, mas, principalmente dava uma subvenção direta da prefeitura aos desfiles. O poder municipal transferia uma determinada quantia para a União das Escolas de Samba (UES) - fundada em 1934 -, que a dividia equitativamente entre suas afiliadas. Ponto interessante a ser aqui destacado é o fato de a verba não ser repassada diretamente às escolas, mas sim a uma entidade representativa das agremiações o que, antes mesmo do decreto oficializando as escolas de samba no cenário carnavalesco, representava a primeira forma de controle. Só receberia dinheiro a escola que fosse afiliada à UES.

O decreto não interferia diretamente na organização interna das agremiações; contudo, ele passou a determinar a estrutura do desfile, "proibindo qualquer manifestação política ou reivindicatória, toda alusão ou crítica aos acontecimentos da época, assim como toda propaganda comercial; determinando o percurso do desfile". (QUEIROZ, 1999, p. 95).

Neste ponto podemos ver que as elites procuravam controlar uma das festas das classes populares, pois o regulamento deixava bem evidente a proibição de qualquer manifestação que viesse reivindicar melhores condições de vida.

A proibição de qualquer crítica ou reivindicação política e socioeconômica, durante os desfiles, constituía um meio de impedir um possível despertar da consciência coletiva. (...) O Estado, representante legítimo das camadas superiores, dominava assim as "sociedades recreativas" inventadas pelos subúrbios e, através delas, domesticava as massas (QUEIROZ, 1999, p. 109-110). 
Negava-se às classes populares a utilização de sua própria criação para exibir os estigmas sociais a que eram condenadas. Embora houvesse a permissão para que desfilassem e até recebessem (pouco) dinheiro para isso, os habitantes dos subúrbios, morros e favelas não poderiam de maneira nenhuma expor suas mazelas em um momento no qual, seguindo a lógica estatal, a festa deveria prevalecer. Para as elites qualquer reivindicação poderia tornar-se um momento perigoso, mas para os habitantes das classes populares "trata-se (...) da busca do futuro sonhado como carência a satisfazer - carência de todos os tipos de consumo, consumo material e imaterial, também carência de consumo político, carência de participação e de cidadania" (SANTOS, 2004, p. 326).

Em vez de domesticação das massas, como afirma Queiroz (1999), prefere-se falar aqui em manutenção das hierarquias ou em "reinversão" da festa, pois a procura de domesticação do povo não ocorria apenas no carnaval - era busca constante. Havia, de fato, uma regulamentação da festa que deveria seguir a ordem imposta pelo poder público.

Concordamos com Queiroz, contudo, quando ela observa que a oficialização e o patrocínio do poder público deixam de ser uma "vitória" das classes populares e tornam-se instrumentos de controle. Ainda que não mais vivêssemos no período abordado por Bakhtin (1999, p. 8), a oficialização das escolas de samba apenas contribui para "consagrar, sancionar o regime em vigor, para fortificálo".

Se por um lado eram instrumentos de manutenção de hierarquias, a oficialização e também a subvenção acabaram por garantir a presença das escolas de samba no cenário do carnaval carioca, mas ainda não interferiam diretamente na concepção dos desfiles.

\section{CARNAVALESCO: CULTURA ERUDITA NA CULTURA POPULAR?}

Peter Burke (2008) alerta para os perigos de se fazer distinção entre cultura erudita e cultura popular. Um desses principais perigos, segundo suas palavras, é a definição de "povo". Seria um todo ou apenas uma parte desse todo? Escolhendo a parte, "corremos o risco de supor a homogeneidade dos excluídos" (p. 41). Se nossa escolha recair no todo ou numa pluralidade, temos um problema que consiste em negar diferenças existentes em um mesmo tema ou, então, exagerá-las.

Seria, portanto, perigoso considerar que existe uma única cultura popular e que é separada totalmente de uma cultura dita erudita. Trilhar esse caminho, no caso das escolas de samba, significaria afirmar que todos os habitantes dos subúrbios e favelas do Rio de Janeiro têm ao menos uma afinidade com as 
agremiações e que todo membro de uma cultura erudita renega completamente a cultura popular.

Temos, contudo, que levar em conta o fato de que as escolas de samba objeto de nosso estudo - são criação da cultura popular e que a chegada do carnavalesco representa um contato direto da cultura erudita com as agremiações.

Interessante observar que os carnavalescos chegam às escolas de samba quase por acaso. O ex-presidente do GRES Acadêmicos do Salgueiro, Nelson de Andrade, responsável pelo enredo e pela confecção do carnaval, soube da existência de um casal de artistas plásticos por meio de uma das frequentadoras da escola, prima da empregada doméstica do casal. O casal, Dirceu Nery, cenógrafo e figurinista pernambucano, e Marie Louise Nery, artista plástica suíça e que já havia sido julgadora dos desfiles das escolas, convidou Nelson de Andrade para ir a seu apartamento. Durante a conversa dos três, Nelson os convidou para ser carnavalescos do Salgueiro e ali decidiram o enredo de 1959 da agremiação: Viagem pitoresca e histórica ao Brasil, que retrataria a missão artística comandada por Jean-Baptiste Debret.

O desfile do Salgueiro em 1959 chamou a atenção de um dos julgadores, que atribuiu melhores notas à agremiação tijucana. Tal fato fez com que, no ano seguinte, Fernando Pamplona fosse convidado por Nelson de Andrade para desenvolver o desfile da escola em 1960.

As agremiações, então, ampliam suas bases sociais com a inserção das camadas médias em seu cotidiano, incluindo cenógrafos e artistas plásticos, conhecidos posteriormente pelo nome de "carnavalescos", que passaram a ser os responsáveis pela produção do desfile (CAVALCANTI, 2008).

Essa entrada das camadas médias nas escolas de samba resultou no afastamento progressivo daqueles que se identificavam com a agremiação e que, mais tarde, implicaria mudança até mesmo do público espectador dos desfiles, outrora predominantemente formado por membros da comunidade (CABRAL, 1996).

Não podemos concordar totalmente com Cabral nesse ponto, pois aqueles que se identificavam com as agremiações delas não se afastaram totalmente; senão, como explicar a presença das velhas guardas nas escolas, formadas em sua maioria por fundadores ou seus descendentes? Concordamos com ele, entretanto, quando afirma que o público que assistia aos desfiles começou a mudar a partir da chegada dos carnavalescos, um público mais interessado no aspecto visual que as escolas de samba passariam a oferecer.

A participação do carnavalesco retira a oportunidade que as classes populares tinham de dar vazão a sua criatividade, de expor seu trabalho ou, como afir- 
ma Rodrigues (1984, p. 42), “o indivíduo que participava diretamente das manifestações culturais de seu grupo, dando formas plásticas e estéticas ao seu poder criador independentemente da sofisticação dessa criação, teve solapada tal oportunidade". A figura do carnavalesco, portanto, chega para atender aos anseios das classes dominantes no que diz respeito àquilo que elas desejavam ver, a seus padrões estéticos de "bom gosto", fazendo com que as escolas de samba passassem a se adequar ao novo público que se formava e estava disposto a pagar para poder assistir a seus desfiles.

Algumas grandes festas brasileiras se desenvolveram e se projetaram nacional e internacionalmente ao deixarem de lado o feitio de 'simples brincadeira' e se assumiram enquanto eventos de organização empresarial (os carnavais fora da época e o desfile de grandes escolas de samba, principalmente as do Rio de Janeiro, talvez sejam os maiores exemplos disso) (MAIA, 1999, p. 194).

A organização empresarial citada pelo autor começa a tomar forma a partir da chegada do carnavalesco, cujo trabalho reforça a transformação do desfile em um objeto mercadológico, dentro da chamada indústria cultural (RODRIGUES, 1984) e essa transformação em mercadoria acaba por incorporar as escolas de samba ao processo de acumulação capitalista, redefinindo-as em termos de formas e significados. (CORRÊA, 2003).

Mesmo que indiretamente, a presença do carnavalesco muda outros elementos que se fazem presentes no cotidiano das escolas de samba, tais como, o samba-enredo, que tem o tamanho de sua letra encurtado e andamento rítmico mais acelerado para que caiba nos discos long play (LP) e mais tarde nos discos compactos (CD) e também, é claro, no tempo de desfile destinado a cada escola; as arquibancadas, que cresceram no mesmo ritmo em que cresceram as alegorias; as fantasias que, muitas vezes, são mais luxuosas do que o próprio objeto representado; e, por último, os enredos, muitas vezes pensados visando a possíveis patrocínios.

Ao contrário do que se possa pensar, a entrada dos carnavalescos nas escolas de samba não se deu de forma amena; ela veio acompanhada de algumas críticas quanto ao modo de "fazer carnaval" desses profissionais.

Sua penetração nas escolas de samba não foi abrupta nem pacífica. Até hoje [1984] sofrem pressões por sua atuação ter sido tão 'inovadora' e por causarem modificações tão profundas. Estas pressões existem tanto entre os componentes quanto entre os elementos da população que conseguem observar criticamente os prejuízos de modificações demasiadamente rápidas (RODRIGUES, 1984, p. 43). 
Voltando ao Carnaval de 1959, a chegada do casal Nery ao Salgueiro, se não sofreu pressão, como diz Rodrigues, ao menos lidou com questionamentos sobre o desenvolvimento do trabalho.

Marie Louise ficou encarregada de fazer o levantamento dos trajes e sua adaptação para as cores do Salgueiro - havia esta preocupação naquela época [e até hoje presenciamos isto nas escolas, digamos, mais "tradicionais"]. No seu português arrevezado [sic], ela tinha que explicar às costureiras do morro, que faziam as roupas das alas, detalhes como altura da bainha, forma da manga, caimento da saia sobre a anágua, enviesado do colete; convencer de que na linha diretório a cintura é embaixo do busto, além de outras especificações. Muita gente reagia. O que é que aquela gringa, alta, magra, com um sotaque brabo, tinha a ver com a escola? (costA, 2003, p. 42).

Os questionamentos feitos pelas costureiras das fantasias do Salgueiro sobre a atuação de Marie Louise Nery confirmam aquilo que Rodrigues (1984) chama de solapamento do poder criador das comunidades e que já descrevemos. Solapar talvez seja palavra exagerada, mas que não deixa de designar certa verdade, já que, no caso descrito, as fantasias passam a ter que seguir a ordem e a maneira de fazer de alguém que estava, até então, fora do cotidiano da agremiação.

Já no carnaval seguinte, quem comandaria os preparativos da escola seria Fernando Pamplona, que aceitara o convite de Nelson de Andrade com a condição de que pudesse manter o casal Nery e também trazer outros profissionais (Arlindo Rodrigues e Nilton Sá). Outra proposta feita por Pamplona foi o desenvolvimento de um enredo sobre Zumbi dos Palmares, proposta prontamente aceita por Nelson de Andrade. O que parecia ser apenas mais um enredo, na verdade gerou um conflito entre os salgueirenses e os artistas plásticos, pois segundo as palavras do próprio Fernando Pamplona, era muito difícil convencer a maioria negra da escola a contar sua própria história, a se fantasiar de escravos, já que o carnaval era um dos raros momentos nos quais eles se podiam tornar reis, príncipes, nobres, etc. Persistia aqui uma tentativa de manter a inversão possibilitada pela festa, inverter a hierarquia, ainda que momentaneamente.

Essa nova composição estética começou a agradar aos julgadores dos desfiles, o que fez com que outras escolas começassem a copiar o modelo de desfile do Salgueiro. Contudo, esses mesmos julgadores passaram também a sofrer críticas por supostamente desconhecer a cultura popular e, muitas vezes, atribuir notas consideradas baixas às agremiações, gerando protestos dos componentes das escolas e também de parte da imprensa (COSTA, 1984). 
Passa a haver, então, uma tensão estruturante baseada na oposição entre "samba no pé" e "visual", na qual o samba enfatiza o aspecto festivo do desfile, a participação através do canto e da música, enquanto o visual acentua o aspecto do espetáculo. Essa tensão entre o samba e o visual possibilitou a expansão e a transformação das escolas de samba (CAVALCANATI, 2008). Foi justamente a valorização do aspecto estético que sofreu a maior parte das críticas por parte dos componentes das escolas e da imprensa, pois, de acordo com suas opiniões, o que estava sendo avaliado era o trabalho artístico do carnavalesco e não a manifestação da cultura popular.

O contato entre a cultura erudita e a cultura popular já se dera antes mesmo da participação dos carnavalescos nas agremiações, haja vista que, em muitos anos, a comissão julgadora era formada por elementos considerados pertencentes às elites, como os casos de Marie Louise Nery e Fernando Pamplona. Portanto, as críticas ao resultado do julgamento em si parecem ser feitas muito mais no calor da insatisfação do que propriamente como um manifesto veemente.

As censuras ao trabalho do carnavalesco continuavam ocupando algumas páginas dos jornais das décadas de 1960 e 1970, mostrando preocupação com os rumos que as escolas de samba estavam tomando. Uma das mais contundentes censuras a essa "profissionalização" das escolas de samba foi a criação, em 08 de dezembro de 1975, do Grêmio Recreativo de Arte Negra Escola de Samba Quilombo, por Antonio Candeia Filho, cujo objetivo principal era manter a "pureza" das escolas de samba e "proteger" a cultura negra de um fim que, segundo ele, estava sendo desencadeado pelas modificações nas escolas de samba.

É justamente nesse ponto que os carnavalescos se defendem, acusando aqueles que se manifestavam contra a sua presença de ser "puristas", de querer reviver uma época cujo retorno já não era mais possível. Para muitos, o próprio acirramento da disputa entre as agremiações (foi célebre a rusga entre Portela e Império Serrano nas décadas de 1940 e 1950) levaria, de uma maneira ou de outra, à profissionalização do desfile. De fato, isso pode ser confirmado, pois Nelson de Andrade, cansado dos sucessivos insucessos dos Acadêmicos do Salgueiro (um terceiro lugar, três quartos lugares e um segundo lugar), foi procurar o casal Nery para, com seu trabalho, impressionar o júri. Vemos aqui que o termo "insucesso" é muito relativo; afinal a agremiação só havia sido fundada após o Carnaval de 1953, ficando sempre entre as quatro primeiras colocadas até 1959 , ano de estreia do casal Nery.

Nelson de Andrade talvez não imaginasse que, ao convidar pessoas que não faziam parte do dia a dia das agremiações, estaria não só mudando a história 
das escolas de samba, como também estreitando a relação entre a cultura erudita e a cultura popular.

\section{CONCLUSÃO}

Ao longo deste artigo se pôde perceber que a cultura popular quase sempre passou por tentativas de disciplinamento por parte das elites, que consideravam tais manifestações festas de barbárie e incivilidade. De acordo com o projeto da elite para o carnaval, não haveria espaço para a inversão, pois o mesmo deveria ser pautado pela ordem e pela hierarquia, principalmente no novo centro urbano que se construíra.

As classes populares, contudo, continuaram mantendo vivas suas manifestações culturais, entre elas, o samba. Interessante notar que foi justamente o tão perseguido samba que estabeleceu contato entre uma elite intelectual e membros da classe popular.

O samba, no final da década de 1920, é transformado por um grupo de jovens compositores desejosos de brincar o carnaval desfilando ao som de suas composições. Fundaram, então, uma agremiação a qual deram o nome de escola de samba.

Outras agremiações começam a surgir no espaço carioca, dando origem a uma competição entre elas que alcança certo sucesso. Com isso, as escolas de samba passam a ser reconhecidas oficialmente, recebendo subvenções do poder público para que pudessem desfilar. Essa oficialização pode ser entendida como uma nova tentativa de controle das classes populares, de manutenção das hierarquias, mesmo que não houvesse interferência direta na concepção dos desfiles.

Com a chegada do carnavalesco ao âmbito das escolas de samba, passa a haver interferência direta na concepção dos desfiles, já que esse profissional fica responsável por todas as etapas da criação do enredo, anteriormente desenvolvidas por membros das agremiações.

A presença de um profissional nas escolas de samba sofreu diversas críticas por interferir diretamente em um elemento da cultura popular, por teoricamente afastar aqueles que as criaram.

Estabelecer o limite entre a cultura popular e a cultura erudita em se tratando de algo tão complexo como uma escola de samba é tarefa bastante difícil, pois ainda que tenha havido uma transformação estética, podemos perceber elementos da cultura popular que persistem, por mais que tenham sido adaptados. 


\section{NOTAS}

1 Hilária Batista de Almeida.

2 Ernesto dos Santos.

3 Há controvérsias em relação à autoria do samba, pois relatos da época apontam para uma criação coletiva.

4 Alfredo da Rocha Viana Filho.

5 João Machado Guedes.

6 Paulo Benjamin de Oliveira.

\section{REFERÊNCIAS BIBLIOGRÁFICAS}

BAKHTIN, Mikhail. A cultura popular na Idade Média e no Renascimento: o contexto de François Rabelais. São Paulo: Hucitec; Brasília: Edunb, 1999.

BURKE, Peter. O que é história cultural. 2 ed. rev. e atual. Rio de Janeiro: Jorge Zahar, 2008.

CABRAL, Sérgio. As escolas de samba do Rio de Janeiro. Rio de Janeiro: Lumiar, 1996.

CAVALCANTI. Maria Laura Viveiros de Castro. Carnaval carioca: dos bastidores ao desfile. 4 ed. Rio de Janeiro: UFRJ, 2008.

CORRÊA, Roberto Lobato. A geografia cultural e o urbano. In: CORRÊA, Roberto Lobato; ROSENDAHL, Zeny (Org.). Introdução à geografia cultural. Rio de Janeiro: Bertrand Brasil, 2003.

COSTA, Haroldo. Salgueiro: academia do samba. Rio de Janeiro: Record, 1984.

. Salgueiro: 50 anos de glórias. Rio de Janeiro: Record, 2003.

CUNHA, Maria Clementina Pereira. Ecos da folia: uma história social do carnaval carioca entre 1880 e 1920. São Paulo: Companhia das Letras, 2001.

FERNANDES, Nelson da Nóbrega. Escolas de samba: sujeitos celebrantes e objetos celebrados - Rio de Janeiro, 1928-1949. Rio de Janeiro: Secretaria das Culturas, 2001.

FERREIRA, Felipe. Inventando carnavais: o surgimento do carnaval carioca no século XIX e outras questões carnavalescas. Rio de Janeiro: UFRJ, 2005.

FRY, Peter; CARRARA, Sérgio; MARTINS-COSTA, Ana Luiza. Negros e brancos no carnaval da Velha República. In: REIS, João José (Org.). Escravidão e invenção da liberdade: estudos sobre o negro no Brasil. São Paulo: Brasiliense, 1988.

GEERTZ, Clifford. A interpretação das culturas. Rio de Janeiro: LTC, 1989.

HAESBAERT, Rogério. Identidades territoriais. In: ROSENDAHL, Zeny; CORRÊA, Roberto Lobato (Org.). Manifestações da cultura no espaço. Rio de Janeiro: Eduerj, 1999.

MAIA, Carlos Eduardo S. Ensaio interpretativo da dimensão espacial das festas populares: proposições sobre festas brasileiras. In: ROSENDAHL, Zeny; COR- 
RÊA, Roberto Lobato (Org.). Manifestações da cultura no espaço. Rio de Janeiro: Eduerj, 1999.

MORAES, Eneida de. História do carnaval carioca. Rio de Janeiro: Record, 1987.

QUEIROZ, Maria Isaura P. de. Carnaval brasileiro: o vivido e o mito. São Paulo: Brasiliense, 1999.

REIS, Letícia Vidor de Sousa. O que o rei não viu: música popular e nacionalidade no Rio de Janeiro da Primeira República. Estudos afro-asiáticos. São Paulo, n.2, p. 237-279. 2003.

RODRIGUES, Ana Maria. Samba negro, espoliação branca. São Paulo: Hucitec, 1984.

SANTOS, Milton. O lugar e o cotidiano. In: SANTOS, Milton. A natureza do espaço: técnica e tempo, razão e emoção. 4. ed. São Paulo: Edusp, 2004. SEBE, José Carlos. Carnaval, carnavais. São Paulo: Ática, 1986.

SOIHET, Rachel. A subversão pelo riso: estudos sobre o carnaval carioca da Belle Époque ao tempo Vargas. Rio de Janeiro: Fundação Getulio Vargas, 1998.

VELLOSO, Monica Pimenta. O modernismo e a questão nacional. In: FERREIRA, J.; DELGADO, L. (Org.). O Brasil republicano: o tempo do nacional-estatismo - do início da década de 1930 ao apogeu do Estado Novo. Rio de Janeiro: Civilização Brasileira, v. 2, 2007.

VIANNA, Hermano. O mistério do samba. 6 ed. Rio de Janeiro: Jorge Zahar, 2007. VOVELLE, Michel. Ideologias e mentalidades. São Paulo: Brasiliense, 1985.

Zilmar Luiz dos Reis Agostinho é mestre em história social pela Universidade do Estado do Rio de Janeiro.

Recebido em: 07/10/2013

Aceito em: 19/01/2014 
